\title{
Occurrence of salmonid alphavirus (SAV) and piscine orthoreovirus (PRV) infections in wild sea trout Salmo trutta in Norway
}

\author{
Abdullah Sami Madhun*, Cecilie Helen Isachsen, Linn Maren Omdal, \\ Ann Cathrine Bårdsgjære Einen, Pål Arne Bjørn, Rune Nilsen, Egil Karlsbakk
}

Institute of Marine Research, Nordnesgaten 50, 5005 Bergen, Norway

\begin{abstract}
Viral diseases represent a serious problem in Atlantic salmon (Salmo salar L.) farming in Norway. Pancreas disease (PD) caused by salmonid alphavirus (SAV) and heart and skeletal muscle inflammation (HSMI) caused by piscine orthoreovirus (PRV) are among the most frequently diagnosed viral diseases in recent years. The possible spread of viruses from salmon farms to wild fish is a major public concern. Sea trout $S$. trutta collected from the major farming areas along the Norwegian coast are likely to have been exposed to SAV and PRV from farms with disease outbreaks. We examined 843 sea trout from 4 counties in Norway for SAV and PRV infections. We did not detect SAV in any of the tested fish, although significant numbers of the trout were caught in areas with frequent PD outbreaks. Low levels of PRV were detected in $1.3 \%$ of the sea trout. PRV-infected sea trout were caught in both salmon farming and non-farming areas, so the occurrence of infections was not associated with farming intensity or HSMI cases. Our results suggest that SAV and PRV infections are uncommon in wild sea trout. Hence, we found no evidence that sea trout are at risk from SAV or PRV released from salmon farms.
\end{abstract}

KEY WORDS: Viral diseases - Pancreas disease - PD · Heart and skeletal muscle inflammation · HSMI $\cdot$ Salmonid $\cdot$ Aquaculture

\section{INTRODUCTION}

Viral diseases represent a major problem in Atlantic salmon Salmo salar L. farming in Norway, with 400 to 500 reported cases annually (Hjeltnes et al. 2016). There are increased public concerns that diseases in salmon farming may have a negative impact on wild salmonid stocks. Most diseases in Norwegian salmon farming are believed to be enzootic and to originate from wild fish, but today farmed fish populations are likely to represent the main reservoirs. Little is known about the spread of viruses from fish farms to wild salmonid populations. Disease outbreaks in farms may lead to substantially increased infection pressure on local wild fish. Exposed susceptible hosts may therefore show ele-

\footnotetext{
*Corresponding author: abdullah.madhun@imr.no
}

vated pathogen prevalence and potentially develop disease. It is challenging to evaluate the impact of diseases in wild stocks since we are normally able to collect only infected but non-diseased fish (McVicar 1997). Such fish may be recently infected or have survived an infection and become carriers.

Anadromous sea trout $S$. trutta L. migrate between river and seawater during their lifecycle. During summer, most sea trout feed in sea areas that are close to their river of origin. Therefore, sea trout in coastal areas with intensive fish farming may be exposed to pathogens spread from disease outbreaks among farmed salmonids. The abundance of sea lice on sea trout has been used to evaluate the local and regional infection pressure from fish farming (Bjørn et al. 2011, Serra-Llinares et al. 2014). The occur-

() The authors 2016. Open Access under Creative Commons by Attribution Licence. Use, distribution and reproduction are unrestricted. Authors and original publication must be credited. 
rence of other pathogens originating in fish farms could also be used as an indicator of infection pressure in an area, if sea trout are susceptible.

Pancreas disease (PD), caused by salmonid alphavirus (SAV), is a major health problem in Norwegian salmon farming, with 89 to 142 annually registered cases between 2011 and 2015 (Olsen \& Taksdal 2016). Two subtypes of SAV occur in Norway, namely SAV3 and the more recently detected SAV2 (Hjortaas et al. 2013). Most of the disease cases due to SAV3 occur in the western part of the country (especially in the county of Hordaland), while SAV2 cases are mostly restricted to an area in central Norway (Møre og Romsdal, Trøndelag). PD is uncommon in northern Norway. Another viral disease, heart and skeletal muscle inflammation (HSMI), is caused by piscine orthoreovirus (PRV). HSMI is an increasing problem in fish farming in Norway, with 134 to 181 cases registered annually between 2011 and 2015 (Alarcon et al. 2016). In the current study, we investigated the occurrence of both SAV and PRV in wild sea trout captured from different Norwegian coastal areas with different farming intensities and disease outbreak frequencies.

\section{MATERIALS AND METHODS}

In total, 843 sea trout were caught using gill nets and fish traps at 10 different sea sites $(\mathrm{A}-\mathrm{J})$ in the counties of Finnmark, Sogn og Fjordane, Rogaland and Hordaland (Fig. 1). The fish used in the current survey were collected as part of the national salmon lice monitoring programme (Serra-Llinares et al. 2014). Sea trout were collected from all 4 counties in 2012 and from only 2 counties (Hordaland and Rogaland) in 2011 and 2013 (Table 1). The fish were caught in the period May to September and stored in individual plastic bags on ice. Length and weight of each fish were recorded on the same day, prior to storage at $-20^{\circ} \mathrm{C}$. At necropsy, a tissue sample from heart (ventricle) was aseptically taken from each trout while still frozen and transferred frozen to tubes on dry ice. The heart samples were sent packed in dry ice to an accredited commercial laboratory (PatoGen Analyse AS) for virus testing. The presence of SAV and PRV was determined by PatoGen using their in-house real-time RT-PCR assays. In brief, an SAV assay developed by Hodneland \& Endresen (2006) was used, targeting the $n s P 1$ gene. This assay detects both SAV2 and SAV3, the subtypes occurring in Norway (Hjortaas et al. 2013). The PRV assay used was as described by Glover et al. (2013), based on sequences published by Palacios et al. (2010). Samples with a cycle-threshold $\left(C_{t}\right)$ value below 37.0 were considered positive.

Scales from selected groups of trout were used to determine river-age (parr) and sea-age. After thawing, each fish was visually inspected for external or internal lesions or signs of disease, and the sex was recorded.

\section{RESULTS AND DISCUSSION}

The objective of the current study was to investigate the potential effect of fish farming on the occurrence of SAV and PRV infections in wild sea trout.

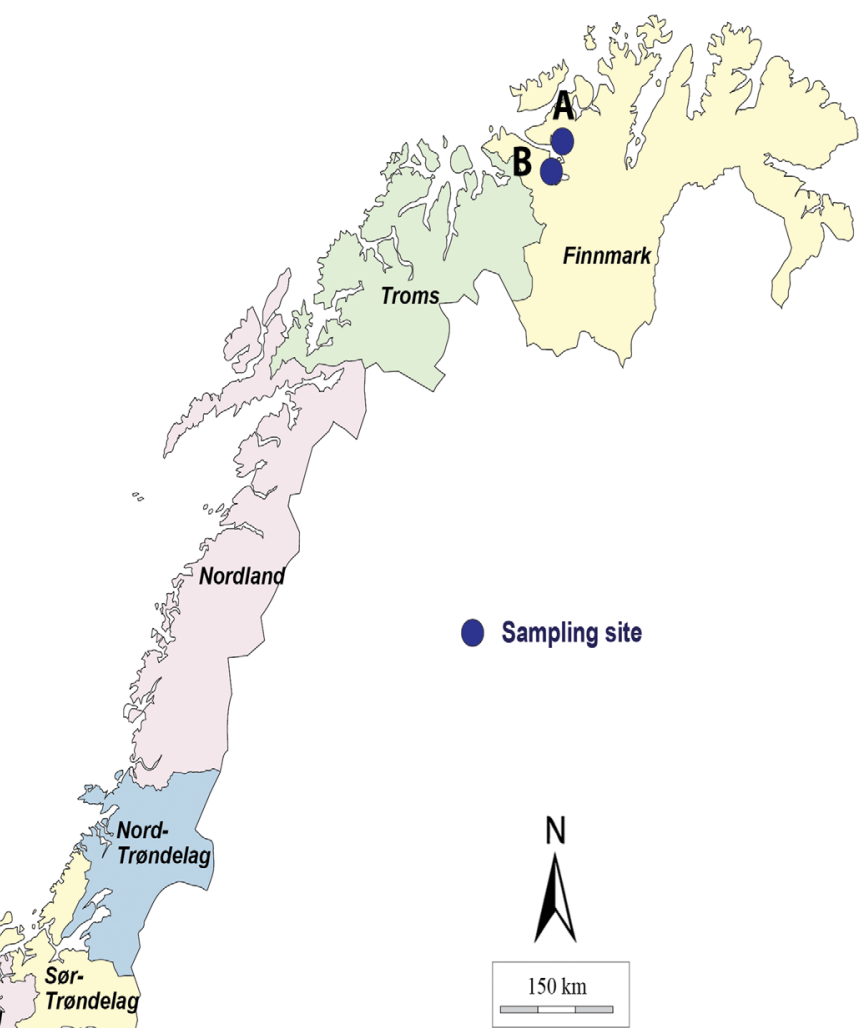


Table 1. Numbers and collection sites (A-J) of sea trout Salmo trutta sampled in Norway during the period 2011 to 2013. Numbers of piscine orthoreovirus (PRV)-positive fish are given in parentheses

\begin{tabular}{|lcccc|}
\hline \multirow{2}{*}{ County } & \multicolumn{3}{c}{ Year } & Total \\
\cline { 2 - 3 } Site (ID) & 2011 & 2012 & 2013 & \\
\hline Finnmark & & $\mathbf{6 9}$ & & $\mathbf{6 9}$ \\
Skillefjord (A) & & 33 & & 33 \\
Talvik (B) & & 36 & & 36 \\
Sogn og Fjordane & & $\mathbf{1 0 0}$ & & $\mathbf{1 0 0}$ \\
Dingja (C) & & 48 & & 48 \\
Balestrand (D) & & 52 & & 52 \\
Hordaland & $\mathbf{7 3}$ & $\mathbf{2 3 3}$ & $\mathbf{1 2 0}$ & $\mathbf{4 2 6}$ \\
Ålvik (E) & 17 & 48 & 40 & 105 \\
Rosendal (F) & 33 & 76 & 41 & 150 \\
Etne (G) & 23 & 109 & 39 & 171 \\
Rogaland & $\mathbf{7 3}$ & $\mathbf{1 1 9}$ & $\mathbf{5 6}$ & $\mathbf{2 4 8}$ \\
Nedstrand (H) & 6 & 36 & 19 & 61 \\
Forsand (I) & $41(4)$ & $45(1)$ & & 86 \\
Hellvik (J) & $26(6)$ & 38 & 37 & 101 \\
Total & $\mathbf{1 4 6}$ & $\mathbf{5 2 1}$ & $\mathbf{1 7 6}$ & $\mathbf{8 4 3}$ \\
\hline
\end{tabular}

Sea trout were collected from 3 counties (Sogn og Fjordane, Hordaland and Rogaland) where PD is enzootic and 1 county (Finnmark) where PD is rarely diagnosed (Olsen \& Taksdal 2016). However, both PRV infections and HSMI outbreaks are common in salmon farms in all 4 counties included in the study (Løvoll et al. 2012, Alarcon et al. 2016).

The average weight and fork length of the collected sea trout was $245 \mathrm{~g}$ (range 16-3116 g) and $25 \mathrm{~cm}$ (range 12-63 cm), respectively. Among the 843 tested sea trout, $440(52 \%)$ were females.

We were not able to detect SAV in any sea trout. Significant numbers of the tested fish were caught in areas where SAV3 is enzootic with frequent outbreaks of PD (e.g. 46, 51 and 28 PD cases were registered in Hordaland in the years 2011, 2012 and 2013, respectively). Because the PCR assay that we used is highly sensitive and specific (Hodneland \& Endresen 2006), it is unlikely that we were unable to detect SAV infection in carrier sea trout. Urquhart et al. (2010) analysed 300 Scottish sea trout without detecting SAV, and Graham (2005) tested sera from 42 wild salmonids from Norway and failed to detect SAV or neutralizing antibodies. Furthermore, SAV was not detected in any of 120 sea trout tested in the Norwegian monitoring programme for brood fish during the period 2012 to 2014 (Garseth et al. 2015). However, there are claims that SAV infections have been detected in a few trout caught in rivers in western Norway (A. Nylund, University of Bergen, unpubl.; cited by Graham 2007).
Using pathogen prevalence in wild fish as an indicator of infection pressure has its limitations (McVicar 1997). Virulent pathogens may cause disease, rendering the host less catchable, or more prone to predation. However, Boucher et al. (1995) showed that injection of PD virus in brown trout did not cause serious disease, and the species was less susceptible to the virus than rainbow trout and Atlantic salmon. That study therefore suggests that SAV is less virulent in sea trout compared to salmon and rainbow trout. Hence, we should be able to detect SAV infections in sea trout if they were common. However, the current and the previously published results suggest that sea trout is rarely infected with SAV. It is consequently unlikely that this species plays a role as a reservoir of the virus in Norwegian coastal waters. However, bath-challenge studies in trout mimicking the natural route of SAV infection are needed to confirm the apparent resistance of the host.

PRV was detected in 11 of the 843 sea trout $(1.3 \%$; Table 1$)$. The $\mathrm{C}_{\mathrm{t}}$ values ranged from 34.0 to 36.9 , indicating a very low amount of virus present. All positive sea trout were caught at 2 sites in Rogaland county (Forsand and Hellvik). Additionally, all positive fish except 1 (10 of 11) were caught in 2011. Prevalence at Forsand and Hellvik in 2011 was 10 and $23 \%$, respectively. The infected fish were collected in May and June (weeks 21 and 24; Table 2).

In Rogaland county, the fish were captured from 3 sites: Forsand, Hellvik, and Nedstrand (Fig. 2). Hellvik is located in an open coastal area with no salmon farming activities and hence may be considered a control area with respect to pathogen transmission from salmon farms. On the other hand, Forsand and Nedstrand areas are located in the inner part of Boknafjord system with high numbers of salmon farms and frequent cases of both PD and HSMI (Hjeltnes et al. 2016). There were 7,7 and 13 registered HSMI cases in Rogaland in 2011, 2012 and 2013, respectively. However, 6 of the 11 PRV-positive trout were collected in the non-farming area (Hellvik). Hence, we found no evidence for an influence from salmon farming on PRV prevalence in the trout. Garseth et al. (2013b) and Marty et al. (2015) found no association between the occurrence of PRV infections in wild salmonids and the number of HSMI cases or salmon farming activities. Our analyses did not reveal any association between PRV occurrence and weight, length, sex or sampling time of year. Older fish could be expected to show a higher 
Table 2. Numbers and collection sites of sea trout Salmo trutta sampled from Hordaland and Rogaland counties, Norway, during the period 2011 to 2013, by week of sampling. Numbers of piscine orthoreovirus (PRV)-positive fish are given in parentheses

\begin{tabular}{|c|c|c|c|c|c|c|c|c|c|c|c|c|c|c|}
\hline \multirow{2}{*}{$\begin{array}{l}\text { County } \\
\text { Site }\end{array}$} & \multicolumn{3}{|c|}{$-2011-$} & \multicolumn{6}{|c|}{-2012} & \multicolumn{4}{|c|}{$-2013-$} & \multirow[t]{2}{*}{ Total } \\
\hline & 21 & 22 & 24 & 14 & 21 & 22 & 24 & 25 & 36 & 22 & 24 & 25 & 26 & \\
\hline \multicolumn{15}{|l|}{ Hordaland } \\
\hline Ålvik & & 17 & & & 20 & & & 28 & & 20 & & 20 & & 105 \\
\hline Rosendal & & 33 & & 12 & & 20 & & 20 & 24 & 20 & & & 21 & 150 \\
\hline Etne & & 23 & & 29 & & 19 & & 20 & 41 & 19 & & 20 & & 171 \\
\hline \multicolumn{15}{|l|}{ Rogaland } \\
\hline Nedstrand & 6 & & & & 16 & & 20 & & & & & 19 & & 61 \\
\hline Forsand & $21(2)$ & & $20(2)$ & & 21 & & $24(1)$ & & & & & & & 86 \\
\hline Hellvik & $10(4)$ & & $16(2)$ & & 15 & & 23 & & & & 37 & & & 101 \\
\hline Total & & & & & & & & & & & & & & 674 \\
\hline
\end{tabular}

prevalence of PRV due to increased probability of exposure, but our data showed no evidence for an effect of river- or sea-age. The higher prevalence of PRV in the Forsand and Hellvik areas in 2011 compared to 2012 or other sampling sites cannot be explained. However, Garseth et al. (2013b) screened some sea trout sampled between 2007 and 2010 for PRV, and also detected infections only in a particular year (2008) albeit in 3 different rivers. In that study, the overall prevalence (2007-2010) was also low (3\%, 4 of 133 fish).

In the present study, the very low virus concentration (indicated by high $\mathrm{C}_{\mathrm{t}}$ values) made it difficult to sequence the virus to determine its genotype. Gar-

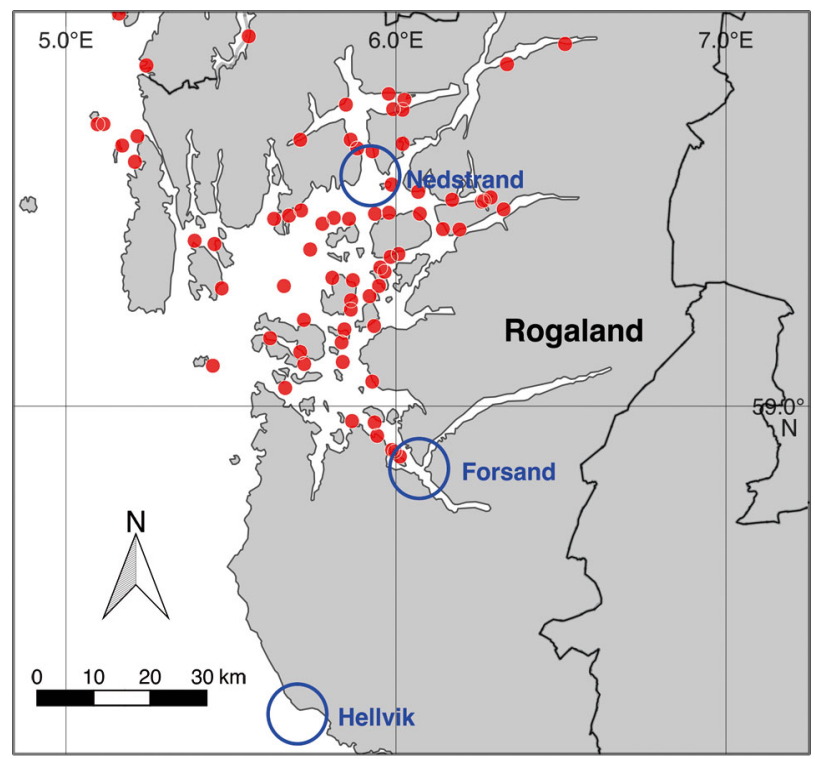

Fig. 2. Salmon farms (red dots) and collection sites (blue circles) of sea trout Salmo trutta in Rogaland county, Norway seth et al. (2013a) were able to genotype the virus from 1 of the 4 infected trout. It belonged to genogroup 1, the most common PRV type in farmed and wild Atlantic salmon in Norway. Hence that infection could possibly be due to virus of farm origin. However, salmonids may also contract PRV infections in fresh water: Indeed, PRV was detected in salmon parr from Norwegian rivers (A. S. Madhun unpubl. results).

Highly virulent pathogens may show low prevalence in wild populations, due to high mortality among infected individuals. No challenge experiments have been performed with PRV in trout. However, PRV infections are ubiquitous in farmed Atlantic salmon (Løvoll et al. 2012), common in escaped farmed salmon (Garseth et al. 2013b, Madhun et al. 2015) and are widespread in wild salmon (Garseth et al. 2013b, 2015, Madhun et al. 2014). High concentrations of the virus have been detected in apparently healthy farmed and wild salmonids without the histopathological changes observed in HSMI (Garseth et al. 2013b, Marty et al. 2015). This suggests that PRV infection may be a prerequisite for HSMI, but additional factors may be needed for the disease to develop. Therefore, it is very unlikely that the low PRV prevalence observed in the seat trout examined to date (Garseth et al. 2013b, this study) is due to high mortality of infected fish. However, a bath-challenge study with PRV in trout is much needed in order to clarify the susceptibility of this species.

The results from the current study show that SAV and PRV infections are uncommon in wild sea trout, and the evidence gathered so far suggests that the species is unlikely to be significantly affected by the spread of these viruses from salmon farms. 
Acknowledgements. The current study was funded by the Norwegian Ministry of Trade, Industry and Fisheries.

\section{LITERATURE CITED}

Alarcon M, Dahle M, Taksdal T (2016) Heart and skeletal muscle inflammation. In: Hjeltnes $\mathrm{H}$, Walde $\mathrm{C}$, Bang Jensen B, Haukaas A (eds) The health situation in Norwegian aquaculture 2015. Veterinærinstituttet Rapportserie 2016(3). Veterinærinstituttet, Oslo, p 28-29 (in Norwegian). Available at www.vetinst.no/Publikasjoner/ Rapportserie/Rapportserie-2016/Fiskehelserapporten-2015

Bjørn PA, Finstad B, Asplin L, Skilbrei O, Nilsen R, Serra Llinares RM, Boxaspen KK (2011) Development of methods for surveillance and counting of salmon lice on wild salmonids. Report fra Havforskningen 2011(8). Havforskningsinstituttet, Bergen (in Norwegian). Available at https://www.imr.no/filarkiv/2011/06/hi-rapp_8-2011_ 1_.pdf/nb-no

Boucher P, Raynard RS, Houghton G, Baudin Laurencin F (1995) Comparative experimental transmission of pancreas disease in Atlantic salmon, rainbow trout and brown trout. Dis Aquat Org 22:19-24

Garseth ÅH, Ekrem T, Biering E (2013a) Phylogenetic evidence of long distance dispersal and transmission of piscine reovirus (PRV) between farmed and wild Atlantic salmon. PLoS ONE 8:e82202

Garseth ÅH, Fritsvold C, Opheim M, Skjerve E, Biering E (2013b) Piscine reovirus (PRV) in wild Atlantic salmon, Salmo salar L., and sea-trout, Salmo trutta L., in Norway. J Fish Dis 36:483-493

Garseth $\AA \mathrm{H}$, Madhun AS, Biering E, Isachsen $\mathrm{CH}$ and others (2015) Annual report on health monitoring of wild anadromous salmonids in Norway. 2014. Institute of Marine Research, Bergen. Available at www.imr.no/filarkiv/2015/ 04/helseovervaking_av_vill_laksefisk_i_norge_2015.pdf/ nb-no

Glover KA, Sørvik AG, Karlsbakk E, Zhang Z, Skaala Ø (2013) Molecular genetic analysis of stomach contents reveals wild Atlantic cod feeding on piscine reovirus (PRV) infected Atlantic salmon originating from a commercial fish farm. PLoS ONE 8:e60924

Graham D (2005) Serological testing of wild salmonids for antibodies to salmonid alphaviruses. DIPNet Newsl 9:1

Graham DA (2007) Salmonid alphavirus (SAV). In: Raynard R, Wahli T, Vatsos I, Mortensen S (eds) Review of disease interactions and pathogen exchange between farmed and wild finfish and shellfish in Europe. Veterinærmedisinsk Oppdragssenter, Oslo, p 41-45

Hjeltnes H, Walde C, Bang Jensen B, Haukaas A (eds) (2016) The health situation in Norwegian aquaculture

Editorial responsibility: Mark Crane, Geelong, Victoria, Australia
2015. Veterinærinstituttet Rapportserie 2016(3). Veterinærinstituttet, Oslo (in Norwegian). Available at www. vetinst.no/Publikasjoner/Rapportserie/Rapportserie-2016/ Fiskehelserapporten-2015

$>$ Hjortaas MJ, Skjelstad HR, Taksdal T, Olsen AB and others (2013) The first detections of subtype 2-related salmonid alphavirus (SAV2) in Atlantic salmon, Salmo salar L., in Norway. J Fish Dis 36:71-74

- Hodneland K, Endresen C (2006) Sensitive and specific detection of salmonid alphavirus using real-time PCR (TaqMan ${ }^{\circledR}$ ). J Virol Methods 131:184-192

> Løvoll M, Alarcón M, Bang Jensen B, Taksdal T, Kristoffersen $A B$, Tengs $T$ (2012) Quantification of piscine reovirus (PRV) at different stages of Atlantic salmon Salmo salar production. Dis Aquat Org 99:7-12

Madhun AS, Biering E, Isachsen CH, Omdal LM and others (2014) Annual report on health monitoring of wild anadromous salmonids in Norway. 2013. Institute of Marine Research, Bergen. Available at www.imr.no/filarkiv/2014/ 06/helserapport_for_helseovervaking_av_vill_laksefisk_ i_noreg-2013.pdf/nb-no

Madhun AS, Karlsbakk E, Isachsen CH, Omdal LM and others (2015) Potential disease interaction reinforced: double-virus-infected escaped farmed Atlantic salmon, Salmo salar L., recaptured in a nearby river. J Fish Dis 38: 209-219

Marty GD, Morrison DB, Bidulka J, Joseph T, Siah A (2015) Piscine reovirus in wild and farmed salmonids in British Columbia, Canada: 1974-2013. J Fish Dis 38:713-728

McVicar AH (1997) Disease and parasite implications of the coexistence of wild and cultured Atlantic salmon populations. ICES J Mar Sci 54:1093-1103

Olsen AB, Taksdal T (2016) Pancreas disease. In: Hjeltnes H, Walde C, Bang Jensen B, Haukaas A (eds) (2016) The health situation in Norwegian aquaculture 2015. Veterinærinstituttet Rapportserie 2016(3). Veterinærinstituttet, Oslo, p 19-23 (in Norwegian). Available at www.vetinst. no/Publikasjoner/Rapportserie/Rapportserie-2016/Fiske helserapporten-2015

Palacios G, Løvoll M, Tengs T, Hornig M and others (2010) Heart and skeletal muscle inflammation of farmed salmon is associated with infection with a novel reovirus. PLoS ONE 5:e11487

Serra-Llinares RM, Bjørn PA, Finstad B, Nilsen R, Harbitz A, Berg M, Asplin L (2014) Salmon lice infection on wild salmonids in marine protected areas: an evaluation of the Norwegian 'National Salmon Fjords'. Aquacult Environ Interact 5:1-16

Urquhart K, Pert CC, Fryer RJ, Cook P and others (2010) A survey of pathogens and metazoan parasites on wild sea trout (Salmo trutta) in Scottish waters. ICES J Mar Sci 67 : $444-453$

Submitted: January 18, 2016; Accepted: May 1, 2016

Proofs received from author(s): June 14, 2016 